\title{
THE PARADOX OF THE FLIPPED CLASSROOM: ONE METHOD, MANY INTENTIONS
}

\author{
Johan Bäcklund, Martin Hugo \\ Jönköping University, Sweden \\ E-mail: johan.backlund@ju.se, martin.hugo@ju.se
}

\begin{abstract}
The Flipped Classroom is a teaching model where content attainment is shifted forward to outside of class, to be followed up by the teacher in class. In Sweden this way of teaching has become very popular during recent years. But what is gained by this way of teaching? Research on the Flipped Classroom in the context of the Swedish High School system is close to non-existent; why studies within this field are of great importance.

In order to find appropriate informants, an electronic survey was constructed. Informants matching the selection criteria were then selected for qualitative interviews. In total nine informants agreed to participate in interviews (semi-structured) to describe their experiences from flipping their own classrooms. The informants reported that the transition from more conventional ways of teaching to using the Flipped Classroom entailed major changes. The informants pointed out that the process of moving away from the more conventional way of teaching improved their teaching. All of the informants expressed they all used the Flipped Classroom methodology but they all did it with different goals in mind and their approach varied a lot. By using the same terminology, it might seem that they worked with the Flipped Classroom in similar ways, but the results show they did not. Herein lies the problem: Teachers say they flip their classrooms, which they do, but they do not share the same goals or approaches, just the term: The Flipped Classroom.
\end{abstract}

Keywords: flipped classroom, flipped education, qualitative interviews, teaching methodology.

\section{Introduction}

In recent years, the Flipped Classroom has become a popular educational form in Sweden. For example, there is a private Facebook group named Flippa klassrummet [Flip the classroom], with as many as 14626 members (April 2018). This can be compared with the international (and public) group the Flipped Class Network, (a group where Jonathan Bergmann (mentioned above) is highly active), which has but 1336 members (April 2018). Research on the Flipped Classroom has mainly been conducted outside of Europe and has often focused on higher education. Thus, such research is not fully transferable to the Swedish school system and the work done by Swedish subject teachers. This is why research of this phenomenon in a Swedish context is of importance. The Swedish school system is undergoing a change: it is becoming more digital and, as society changes, the school must follow (Kroksmark, 2013). The Flipped Classroom can then be a natural way of meeting increased demands (Skolverket, 2011; Skolverket, 2013) with respect to the use of modern technology in teaching. However natural or not, if a lot of teachers in Sweden use this way of teaching, is it not also important to find out what this way of teaching means and what it could mean in terms of learning?

The 'Flipped Classroom' (Bergmann \& Sams, 2012; Mazur 1997/2014; King, 1993), 'Flipped Learning' (Bergmann, 2017) or the 'Inverted Classroom' (Lage, Platt \& Treglia, 2000; Strayer, 2012) are all names for a teaching method/educational form where part of the teaching, especially with respect to the introduction of new material, is placed outside the classroom. The 


\begin{abstract}
PROBLEMS
OF EDUCATION

IN THE $21^{\text {st }}$ CENTURY Vol. 76, No. 4, 2018

452

activity that takes place outside of the classroom is called the flip. The teaching that is provided in this scenario takes its starting point from the students' understanding of the flip. The Flipped Classroom can be first traced to the 1980s (Johnson \& Renner, 2012). King (1993) describes a student-centered form of teaching that includes a changed teacher role as indicated in the following title: The Sage on the Stage to the Guide on the Side. King, however, does not use the term Flipped Classroom. In conjunction with the technical conditions that developed around the turn of the millennium, Baker launched the concept of the 'Classroom Flip' (Baker, 2000). Bergmann and Sams (2012) also present Mazur (1997/2014) as a foreground figure in researching and presenting the Flipped Classroom. We also note that Bergmann and Sams (2012) began to use the concept 'flip' in 2007.
\end{abstract}

\title{
Previous Research
}

The majority of the previous research into Flipped Classrooms has been conducted within the context of higher education (see, for example, Bishop \& Verleger, 2013) By 2012, 24 studies of relevance to the Flipped Classroom had been identified (Bishop \& Verleger, 2013). In subsequent years, several additional studies have appeared that illustrate more closely the effects of the flipped classroom (see, for example, Atteberry, 2013; Enfield, 2013; Gross, Pietri, Anderson, Moyano-Camihort, \& Graham, 2015; Jensen, Kummer, \& Godoy, 2015; Johnson \& Renner, 2012; Jonsson, 2015; McLean, Attardi, Faden \& Goldszmidt, 2016; van Vliet, Winnips \& Brouwer, 2015).

In his dissertation, Strayer (2007) makes a comparison between different student experiences of Flipped- and non-flipped classrooms respectively. Strayer's conclusions show that there are pros and cons associated with both forms of teaching (other comparative studies include Herreid, \& Schiller, 2013; Jensen, Kummer, \& Godoy, 2015; Mattis, 2015). The benefits of the Flipped Classroom, as claimed by Strayer (2007), are that students become more active compared to the more conventional classrooms and that communication increases between the participating students as well as between the students and the teacher. A number of other studies also show that student activity in the classroom increases as a result of flipping the classroom (Bates \& Galloway, 2012; Enfield, 2013; Kjellin \& Birkenkrahe, 2015; McLean et al., 2016; van Vliet et al., 2015; Zhi Chen, 2014). Enfield (2013) and McLean et al. (2016) show, for example, that flipping the classroom resulted in the students becoming more active and taking greater responsibility for their own learning, noting that the students had videos as a resource that could be used for repetition and in cases where a student was absent. In addition to increased student activity, Zhi Chen (2014) also found that, as a consequence of the Flipped Classroom methodology, the students enjoyed a deeper understanding of the content that was taught.

Van Vliet et al. (2015) conclude that the Flipped Classroom improved the students' metacognition and collaborative learning. However, Atteberry's (2013) results show that there are no clear effects of the Flipped Classroom unless there is a continuity in the use of the method; deep learning only occurs when there is a recurrence of the model in the classroom. Deep learning does not take place when it is used only occasionally. Enfield (2013) reports in his research that the students' ability to trust in themselves, as they acquire new material, was found to increase through the use of the Flipped Classroom. Enfield (2013) and Jonsson (2015) state that students appear to experience enhanced learning through the Flipped Classroom methodology compared to the more conventional classroom. In Jonsson's research, the results of two groups were compared to each other; one group used the Flipped Classroom methodology, whilst the other group was exposed to the course content via more conventional teaching methods. The student approval rates on the course were measured at 81 percent in the Flipped Classroom, compared to 60 percent in the more conventional classroom. In addition to the difference in approval rates, Jonsson presents results showing that the students in the Flipped Classroom received higher grades. 
Johnson and Renner (2012) compared the results of two student groups. One group was taught in a teacher-centered classroom (a conventional classroom) and the other group was taught in a student-centered (Flipped) classroom. Johnson and Renner's results, however, show that there was no difference between the different groups. Jensen, Kummer, and Godoy (2015) also conclude that there are no differences between surface- and deep learning in a Flipped Classroom versus a conventional classroom. They conclude that neither the learning of a certain subject content nor the attitude of the students towards the course were improved by the Flipped Classroom methodology.

Brown's (2012) research, conducted from a teacher's perspective, shows that flexibility increases for both teachers and students when the Flipped Classroom methodology is used. The increased flexibility involved issues of scheduling, planning, and a transformation of how time spent in the classroom was used. One negative effect for teachers who employ the Flipped Classroom is that their workload increases (Atteberry, 2013; Avdic \& Åkerblom, 2015; Enfield, 2013) because of the time it takes to build a video library. The students' opinions of the recorded material also show that they have a low tolerance for any errors in the videos (Enfield, 2013), which, in turn, puts pressure on the teacher to deliver the content well above an adequate level.

Other effects of the Flipped Classroom are, for example, reported in Solstuen's (2014) research of how ICT is used in the classroom. The research shows that the motivation of the students increased. The role of the teacher also changed; the teacher became more of a guide, albeit on the sidelines, instead of a traditional 'lecturer' (see King, 1993). Other results in Solstuen's research showed an increase in the amount of interaction in the classroom, increased individualization, and an increase in the students' overall digital competence.

\section{Research Focus}

The purpose of this research is to examine Swedish subject teachers' experiences of Flipped Classrooms consequently due to the fact that it has become a widely spread teaching methodology, but with close to none existent knowledge in what the method actually does in relation to educational research. Each of the informants who were interviewed for this research all had at least six months' experience of using the method. The research questions addressed in this research are: What does the Flipped Classroom mean to the informants? What characterizes Flipped Classrooms? and What opportunities and obstacles can be identified from a close analysis of the informants' descriptions?

\section{Methodology of Research}

Firstly, to find informants with experience of teaching in the Flipped Classroom, an electronic survey was constructed and uploaded online to the Facebook group Flippa klassrummet [Flip the classroom]. The survey was online for two weeks in February 2016. By then 42 informants had replied to the survey. Secondly, informants matching the selection criteria were then selected for qualitative interviews. The selection criteria in this study were that the informants had to have teaching experience for at least two years; worked with traditional, conventional, teaching methods for at least one year as well as they should be currently working with the Flipped Classroom method and has done so for at least six months. Additionally, they also had to, through the survey, communicate about both positive and negative experiences from working with the Flipped Classroom. Nine informants agreed to participate in interviews (semi-structured) to describe their experiences from flipping their own classrooms. The selected informants, all of them subject teachers, geographically spread all over southern Sweden, were interviewed during the spring of 2016.

\author{
PROBLEMS \\ OF EDUCATION \\ IN THE $21^{\text {st }}$ CENTURY \\ Vol. 76, No. 4, 2018 \\ 453
}


Johan BÄCKLUND, Martin HUGO. The paradox of the flipped classroom: One method, many intentions

$\begin{array}{r}\text { PROBLEMS } \\ \text { OF EDUCATION } \\ \text { IN THE 21 } 1^{\text {st }} \text { CENTURY } \\ \text { Vol. } 76 \text {, No. 4, } 2018 \\ \hline 454\end{array}$

\section{Qualitative Interview}

The key point in the gathering of the data that was Kvale's (Kvale \& Brinkmann, 2014) use of qualitative research interviews where the purpose is to understand and describe the informants' experiences of the Flipped Classroom. The seven stages associated with this particular methodology presented by Kvale and Brinkmanns (op. cit.) are (i) thematizing, (ii) designing, (iii) interviewing, (iv) transcribing, (v) analyzing, (vi) verifying, and (vii) reporting. The data collection process consisted of semi-structured interviews that were constructed with open questions requiring responsiveness on the part of the researcher in following up of the informants' responses.

\section{Data Collection}

Data collection was carried out in two steps, with the first step aimed at identifying a criteria-based target group (Dalen, 2013; Malterud, 1998) consisting of certified high school subject teachers with experience of both the Flipped Classroom and more traditional teaching methods. The starting point rests on the assumption that the selection could provide highly relevant results for those who work with, or are curious about, the Flipped Classroom. An electronic survey was uploaded, with the aim to identify possible informants matching the selection criteria, to the Facebook group Flippa klassrummet. The participants who were initially selected included 42 teachers who responded to the questionnaire within two weeks in February 2016. Ten of these 42 teachers matched all of the selection criteria and nine of them agreed to participate in the interview study (see Figure 1).

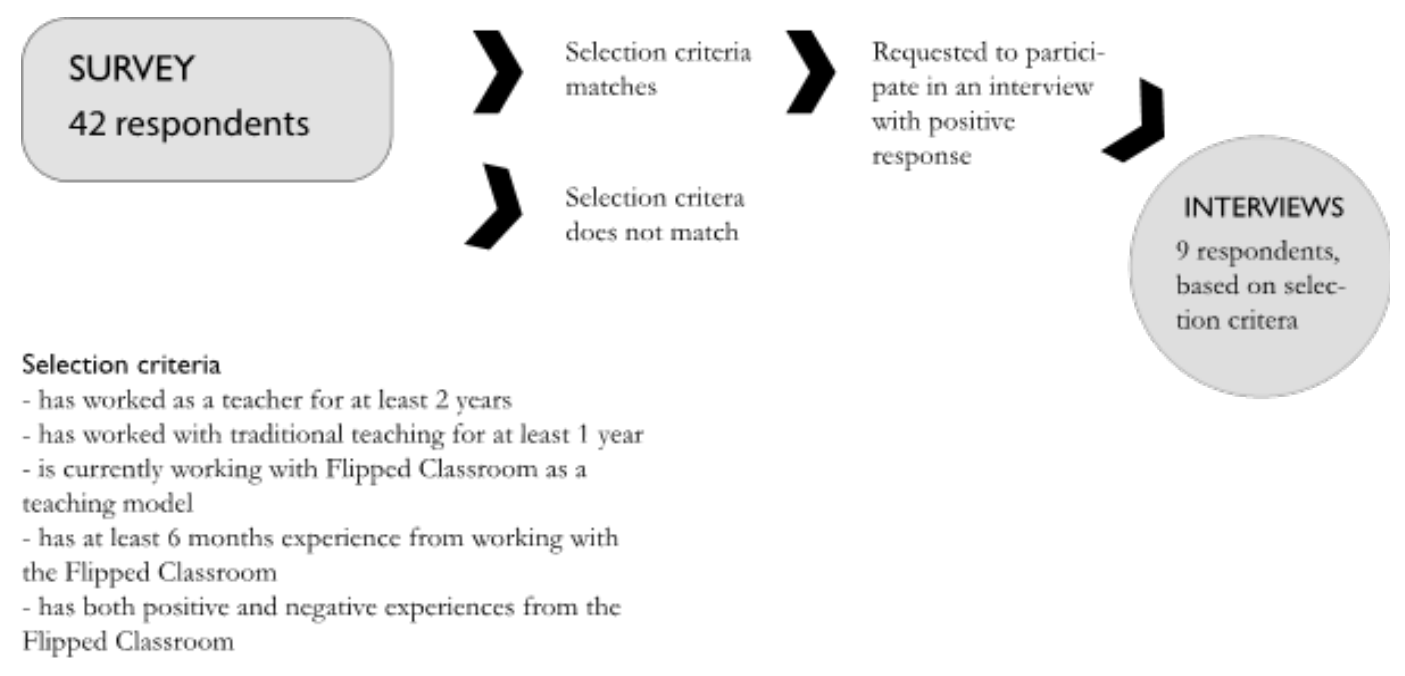

Figure 1. The selection process.

\section{Informants}

Five of the nine informants who were selected for the interview were active in grades 7 through 9, and four of the nine were High School teachers. The school subjects that were represented by these informants included Mathematics, Spanish, English, Chemistry, Physics, Swedish, Biology, History, Social Sciences, Religion, and Geography. Conducting the interviews was time-consuming because the candidates who were selected were geographically spread across southern Sweden and the interviews were conducted at the respective informants' schools. The duration of each interview was between 40 and 75 minutes. All of the interviews were recorded and transcribed. Table 1 shows an overview of the nine informants who were interviewed: 
Table 1. Overview of informant characteristics.

\begin{tabular}{llllllllll}
\hline Informant & $\mathbf{1}$ & $\mathbf{2}$ & $\mathbf{3}$ & $\mathbf{4}$ & $\mathbf{5}$ & $\mathbf{6}$ & $\mathbf{7}$ & $\mathbf{8}$ & $\mathbf{9}$ \\
\hline Age & 55 & 43 & 54 & 38 & 33 & 39 & 56 & 44 & 45 \\
\hline Teaching certificate & $\mathrm{Y}$ & $\mathrm{Y}$ & $\mathrm{Y}$ & $\mathrm{Y}$ & $\mathrm{Y}$ & $\mathrm{Y}$ & $\mathrm{Y}$ & $\mathrm{Y}$ & $\mathrm{Y}$ \\
\hline Age of students & $13-16$ & $13-16$ & $16-19$ & $13-16$ & $16-19$ & $13-16$ & $13-16$ & $13-16$ & $16-19$ \\
\hline Overall teaching experience (yrs.) & 14 & 15 & $20+$ & 17 & 5 & 13 & $20+$ & 15 & 17 \\
\hline Flipped teaching experience (yrs.) & 2 & $3+$ & $3+$ & 1 & 2 & 1 & $3+$ & 3 & 3 \\
\hline $\begin{array}{l}\text { Positive experiences (flipped teaching) } \\
\text { Negative experiences (flipped teach- }\end{array}$ & $\mathrm{Y}$ & $\mathrm{Y}$ & $\mathrm{Y}$ & $\mathrm{Y}$ & $\mathrm{Y}$ & $\mathrm{Y}$ & $\mathrm{Y}$ & $\mathrm{Y}$ & $\mathrm{Y}$ \\
ing) & $\mathrm{Y}$ & $\mathrm{Y}$ & $\mathrm{Y}$ & $\mathrm{Y}$ & $\mathrm{Y}$ & $\mathrm{Y}$ & $\mathrm{Y}$ & $\mathrm{Y}$ \\
\hline
\end{tabular}

\section{Qualitative Content Analysis}

The interviews were analyzed by means of a qualitative content analysis with a latent abstraction level, which means that the researcher interpreted the content of the interview (Graneheim \& Lundman, 2004). According to Elo and Kyngäs (2008), the purpose of such a content analysis is:

$[\ldots]$ to attain a condensed and broad description of the phenomenon, and the outcome of the analysis is concepts or categories describing the phenomenon. Usually the purpose of those concepts or categories is to build up a model, conceptual system, conceptual map or categories. (Elo \& Kyngäs, 2008, p. 108)

The analysis was carried out in three steps that were inspired by Creswell (2014), Larsen (2009), and Tesch (1990): ducted.

Step 1 The interviews were transcribed, and an initial scan of the material was con-

Step 2 Careful reading of all interview transcriptions. The reading generated an overview of the material and gave some insight into what appeared in the material. Some descriptions were shared by the majority of the informants and some descriptions were unique.

Step 3 The material was encoded by keywords and phrases in the statements. Then, the material was read through again and the researchers designed five key content categories that appeared on the basis of the keywords.

\section{Ethical Issues}

The four basic ethical requirements for research in Sweden were taken into account: the information requirement, compliance requirement, the confidentiality requirement, and the utilization requirement (Bryman, 2015; Dalen, 2013; Kvale \& Brinkmann, 2014; Swedish Research Council 2016). The informants were informed about the purpose of the research and they were informed that their participation was voluntary and that they had the right to discontinue their participation in the research at any time. For this research, all of the informants gave their consent to participate in the research. In the handling of personal data, the names of the informants were stored together with the collected material. The material was coded, and the informants were treated confidentially. Regarding the utilization requirement, the informants were informed about what the collected material would be used for. 
Johan BÄCKLUND, Martin HUGO. The paradox of the flipped classroom: One method, many intentions

\section{PROBLEMS \\ OF EDUCATION \\ IN THE $21^{\text {st }}$ CENTURY \\ Vol. 76, No. 4,2018 \\ 456 \\ Results of Research}

All of the informants reported that the transition from more conventional ways of teaching to using the Flipped Classroom methodology entailed major changes. The instructions and micro lectures had to be transferred to activities that took place outside the classroom resulting in students coming to class better prepared. The flipping of the classroom requires, according to the informants in this research, a new perspective on education and a new approach to teaching. This put more pressure on the informant, especially with regards to planning and structuring lessons. The informants claimed that they continually began producing their own material in the form of recorded content (films) that students took part of before coming to school. The research also shows that the informants took different approaches to the Flipped Classroom, as well as having different purposes with the method. However, all of the informants pointed out that the process of moving away from the more conventional way of teaching to using the Flipped Classroom improved their teaching. Five themes were identified that covered what the Flipped Classroom means to the informants and what they thought characterize this method. These themes are: Changed Professional Practice, Time Efficiency, Technology Opportunities and Obstacles, Participation, Motivation and Continuity for Students, and Visible Learning.

\section{Changed Professional Practice}

One thing that emerges in all of the informants' statements is the change in their professional practice. Their professional practice changed so that it became more student-centered than before, thus requiring a deeper level reflection by the teachers. Teacher 7 reported that:

The biggest thing [...] is the flip inside my own head... what is important in my way of teaching? [...] one has to rethink the whole teaching process and that's the biggest thing with the whole Flipped Classroom to me, that I have to think about What? How? and Why?

Teachers 2, 6, and 9 reported that their instructions transferred from being delivered inside the classroom, at the start of each class, to outside the classroom in the shape of the flip. They also felt that the time that they spent together with their students was spent doing "the most important things: the reflections and the discussions" (Teacher 2), since students come more prepared to each class. Teacher 9 explained the mental transition from the conventional way of teaching to the Flipped Classroom as the following:

Before, I just used the whiteboard, the classical way, just jotting a few things down, turning toward the class and saying: "This is how it works! Are you guys with me?" What made me leave that way of teaching was the fact I became aware that I just...I just wrote some grammar principles on the whiteboard. [...] But then, then I asked myself "What's next?" and "What do I want to achieve with this?" Do I just want them to "fill in the blanks" or do I want them to be able to use the phrases, the grammar in practice? I want them to be able to talk, to use their language; words, etc. Isn't that what I want them to be able to do?

Teacher 1 claimed that by using the Flipped Classroom means his teaching had become more student-centered and more based on his students' questions. This was a consequence of them already having listened to and having watched "the big orientation of today's class and can further deepen their knowledge by asking more precise questions when in the classroom." Teacher 7 stated that the Flipped Classroom forces the teacher to be more prepared than ever and that the teacher has to broaden the students' horizon in regard to their understanding of the content being taught:

As a teacher, I'm in constant reflection over the way I teach, there's an openness about it; that my students have access to the content before class, nothing is supposed to take place behind 
closed doors and if I can't stand up for the way I organize my teaching, I think I'm walking on
thin ice.

The increase in depth and breadth of students' preparations for class, according to all of the informants, is one effect that is caused by the changes in the way teachers and students communicate through the Flipped Classroom methodology, as well as from changes in their relationship. A more nuanced and more direct communication takes place in the classroom when the students ask properly thought-through questions from the flips they have taken part in:

More often than not, I can start on a more advanced level, or, alternatively, move ahead a lot faster. And then, the feedback presented to me is more thoughtful due to the process inspired by the method, my students can be more precise when asking questions, as well as when they discuss various topics. (Teacher 1)

Teacher 9 claimed that the Flipped Classroom enables the students to ask more questions and increases the level of communication. Teachers 3, 4, 6, and 8 said that they spent more time with each student, in every class, as a consequence of each class being more structured because of the Flipped Classroom methodology (as compared to the more conventional classroom). Furthermore, when the students are more prepared, then a more equal relationship between students and teachers prevails. The change in the communication in the classroom is not the only change with respect to how students and teachers communicate; several teachers experienced different forms of communication through digital platforms (learning management systems) as well as through SMS (short message service):

[...] I have my students on an SMS-chat so when they are watching the flip at home, every once in a while, I receive an SMS: "Hey, I'm not sure I'm getting this" [...] I get more questions. The questions can "pop up" in the evening, or in the morning...that's a consequence of this...had this been in the classroom, me talking there, these questions probably wouldn't have been asked. (Teacher 2)

The quote from Teacher 2 indicates that when using the Flipped Classroom methodology, communication outside the classroom, which previously did not exist, occurs. Moreover, this is also concluded by Teacher 3 as we can see in the following remarks: "We are with the students; in their homes, even though we're not. We are 'present' with the students at home and help them at home, but from a distance."

\section{Time Efficiency}

Most of the informants reported that the time spent on planning their classes increased, as well as the time spent on implementing the method when they began to use the method. Specifically, the recording sessions consumed a great deal of time. However, once the Flipped Classroom was fully implemented, the teachers actually saved time. With respect to the recording sessions it is crucial that the teacher has access to a work space where interrupts to the workflow do not occur:

The negative aspect is that it takes time to record your material. And you have to have access to a quiet place where you can record. Because if someone walks in while you're recording, you have to start all over again. (Teacher 6)

Teacher 8 also discloses that planning lectures using the Flipped Classroom methodology is time-consuming, but nevertheless, the teacher draws the conclusion that overall work hours actually decrease: 


\author{
PROBLEMS \\ OF EDUCATION \\ IN THE $21^{\text {st }}$ CENTURY \\ Vol. 76, No. 4, 2018 \\ 458
}

Planning consumes more time [...] However, I do save time if I look at the bigger picture. Mainly because my students understand the content better [...] You get a completely new way of thinking about school and learning when you're flipping your classroom and they do their homework because they find it meaningful and fun, actually. And this saves time, a lot of time, just because they come prepared. So, a lot of time planning is required, but in the long run, you are actually saving time.

All of the informants stated that the time that they invested in planning their recordings was time given back to them in the future since they could re-use the materials that they had developed: "In the long term, this definitely generates time saved. I'm absolutely sure about it." said Teacher 1 . This long-term advantage is also described by Teacher 9 :

It gives me an advantage when I'm looking forward to next year. Then I already have a material to (re)use and that, to me, feels very good, it eases my workload for the coming year, or semester.

The informants also described a significant time gain when class is in session: "The most significant change is that we spend more time working in class" (Teacher 3), "[...] you know... that we spend the time thinking." (Teacher 2), "It's the time, that we are more efficient during classes...time gains" (Teacher 7), or, as Teacher 4 described it: "We all become more efficient during classes and the students get more out of it, I think."

Some of the informants also reported on why they feel less time pressure than what they used to feel in the more conventional classroom:

The time gain, to me as a teacher...I experience less stress [...] instead of feeling the pressure that I need to move forward through my planning the whole time and being interrupted, or afraid of being interrupted...that stress is now gone. (Teacher 3)

\section{Technology Opportunities and Obstacles}

During the interviews, several sentiments emerged regarding the technology which is often used when flipping the classroom. The teachers described technology as an obstacle to overcome. Some of the teachers also expressed insecurities about publishing their video materials online, for example, on YouTube. A few informants claimed that one has to be quite tech savvy to be able to cope with the method. Teachers 2, 4, 5, and 6 all stated that there are several steps involved in recording and publishing the content. Firstly, one needs to set up all the technology and then record the session. Then one needs to review the recording and after that, if all is well, publish the recording. Secondly, you need to distribute the content to the students. The teachers claimed that this process might actually deter other teachers from using the Flipped Classroom methodology. Teachers 1 and 9 stressed the importance of overcoming these obstacles and pointed out that by using digital tools through the Flipped Classroom one satisfies the requirements of using digital technology in accordance with the Swedish school curriculum.

One of the advantages with using technology, according to the teachers, is the availability of the produced materials. Students can easily access the materials whenever they need to. Furthermore, the students are not limited to just the current materials that are being used; they also have access to older materials as well. The availability of a variety of materials also assists both teaching and learning whenever a student or a teacher is absent from school. Such situations are made easier for substitute teachers as well. Most teachers also experience a feeling of stress-relief because of the ease with which students can access the materials. The availability and accessibility of materials is one obvious reason why teachers might flip their classroom. As one of the teachers put it: "The immediate advantage is that there are always materials for students to access, even materials from last month, or last semester." (Teacher 1). Comparably, Teacher 2 reported: "To have all the materials as a resource, always there, a resource always 
expanding". This immediate availability of materials serves the students well since they never need to stop their studies and wait for help (their teacher) because they are always able rewatch the materials they are having difficulties with and move on in their learning. Some of the informants claimed that students who had difficulties in understanding certain subject content benefitted from the Flipped Classroom: "I have a lot of students experiencing problems with understanding the content that feel that it's great that they can watch and listen to my instructions over and over again if they need to. It is repetition for a test." (Teacher 2).

\section{Participation, Motivation and Continuity for Students}

One key aspect in the teachers' descriptions of the Flipped Classroom concerns student motivation. The students' increased involvement in what takes place inside and outside the classroom requires continuity: "There's no point flipping your class randomly, every once in a while, like once a month; you have to work with this method every week" (Teacher 3).

Superordinate to the Flipped Classroom teaching method, according to Teacher 6, is the claim that the method needs to be rooted with the students: "[...] they need to see and understand the pros of the teaching method." The teacher needs to motivate the students as to why this method is used and connect the flip with meaningful activities so that "they feel, when they come to class, that this flip, this homework, is followed up in a good way, that both the flip and the activity correlate with each other and thus make sense to them" (Teacher 3 ). "It's so much about what we do in our classroom, you know, the activity after the flip", Teacher 2 concluded. Several of the teachers in the research argued that one of the purposes behind flipping the classroom was to motivate their students by preparing them for the content, making sure there was time to reflect on, and to think about the content. This made the students more involved in the learning processes.

Teacher 2 stated that the benefits that the Flipped Classroom gives rise to when students view content online is that the students are given time to process the information they receive, perhaps several days before the actual class takes place. This teacher reported that "students are given time, time to talk, especially time to think before one talks. Right now, I feel that the results of this method are really [expletive] great."

A similar experience was described by Teacher 1, who reported that the students stay on top of things from the beginning and that this is one of the key purposes to flipping the classroom. This teacher noted that "we start on a whole different level, not always on the lowest level". Teacher 6 also thought that the start of each class was different than before:

The purpose of flipping is that... when they watch it before class and come prepared to class... and I don't start at the same place, with the same material I used to. Prior to flipping, one had to go through the whole theory; a whole lot of instructions. (Teacher 6)

Teacher 2 suggested that flipping the classroom implied the feeling that "you're one step, one lesson, one class, ahead - the whole time." A similar experience was described by Teacher 1 :

The purpose is that students come relatively prepared to class... an example is Mathematics, they are ready to start practicing their skills from the moment they enter the classroom. That is, what I would conclude to be the major purpose of flipping the classroom. And they can ask relevant questions when given access to instructions/content prior to our meeting.

\section{Visible Learning}

Teachers 2, 3, and 7 talked about their students' learning and progression through the course as becoming more visible in the Flipped Classroom. This is mainly due to the fact that activities in class are more student-centered and offer more opportunities for discussion and 
Johan BÄCKLUND, Martin HUGO. The paradox of the flipped classroom: One method, many intentions

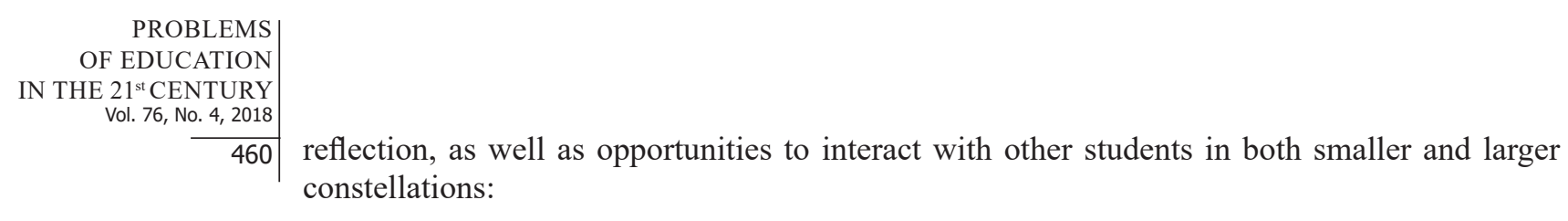

[...] where they develop skills to argue for their opinion, or their ability to listen. Analysis and stuff like that. Listen to others, come to their own conclusions and listen to someone else's opinion and conclusions and then come up with a new hypothesis and/or draw conclusions from it.

Through the social interaction that is promoted by the Flipped Classroom, Teacher 3 reported that students learn more from each other than before. Teacher 7 pointed out that the interaction following a flip is of great importance, since students "have solutions to problems" that become visible.

Above all, I think that one establishes a better contact with the less motivated students. I feel that this method makes it easier for them to access the content being taught. In my experience, they perform better on tests than they would have if I had the same students a couple of years ago, before I flipped my classroom.

The purpose of Flipped Classroom, according to Teacher 4, is to make students' learning visible through questions: "students can, and will, ask questions and this helps me to formatively assess my students' knowledge." Teacher 8 explained the situation thus:

I can support them more in their learning process; they can ask questions, they won't get stuck...they can always move forward. I think that's where the learning takes place [...] instead of coming to class just to sit and listen to something I read from the same book they're reading. They want to be able to discuss... get help... be able to sit down and write whilst having my support and supporting each other.

Through receiving formative assessment, students become aware of their own learning processes. "When they know this, they become an active agent of their own learning process, which they couldn't accomplish through the conventional classroom." (Teacher 7). This increase in the students' self-awareness, when students become aware of their own learning was something Teacher 6 experienced in her Flipped Classroom:

It's actually quite a funny story, because when I started out, started flipping my classroom 4-5 years ago, it's four years...yeah. Well, when I held my progress discussions last semester several of my students told me things like: "When we started working with the Flipped Classroom, I could easily lie in bed watching the videos. However, I eventually realized that these are the instructions we get; I need to take notes in order to remember the content." So, the way I see it, my students needed to actively engage in watching and listening; taking notes. And it was not me who made them realize it, they did, themselves.

\section{Discussion}

Research conducted on the Flipped Classroom in the context of the Swedish high school system is close to non-existent. Even when examining international literature on the Flipped Classroom (Atteberry, 2013; Bates \& Galloway, 2012; Enfield, 2013; McLean et al., 2016; Strayer, 2007; van Vliet et al., 2015), research that is connected to the teachers experience of the Flipped Classroom is scarce, since most studies focus on the students' perceptions and the method itself. In this research, high school subject teachers in Sweden were given the opportunity to reflect upon their way of working with the Flipped Classroom methodology. The selection of the informants in this research was based on the criteria (amongst others) that they had both positive and negative experiences of using the Flipped Classroom. The Flipped Classroom includes an array of different methods and ways of teaching different subjects in schools. The result of this research shows that there are no certain distinctions as to how one should 
teach using the Flipped Classroom methodology. The teachers in the research reported that the advantages of the method are that the flip is preparatory to the understanding of the subject and that students are able to discuss the content together with other peers in the classroom in a qualitatively better way.

The teachers in the research describe that their professional practice changed when they flipped their classrooms. The change that they described was that they became more like supervisors in the classroom. This was due to the fact that the students, after they had taken part of the information (the flip), became more familiar with the subject content when they attended the lessons, and could then, by virtue of this increased familiarity, could become more involved in classroom discussions. This is comparable to several previous studies (Enfield, 2013; McLean et al., 2016; van Vliet et al., 2015; Kjellin \& Birkenkrahe, 2015; Bates \& Galloway, 2012; Strayer, 2017; Zhi Chen, 2014) where it was observed that communication and student activity in the classroom increases when the Flipped Classroom methodology is implemented consistently. The teachers in this research also report that flipping the classroom meant that time was freed up during the lessons, thus enabling increased communication (both quantitatively and qualitatively) between the teacher and the students about the subject content that was being taught. The teachers stated that this increase in communication contributes to the students' clearer view of their own learning through the flips. The teachers also found that formative assessment processes were facilitated by this teaching method (see Hattie, 2012).

Two of the findings in this research may discourage teachers from starting to flip their classrooms. These potential obstacles are (i) working hours and (ii) the use of technology. The teachers in the research reported that the frequency of communication with students also increases outside the school when they flipped their classrooms. Several teachers reported that, after they had flipped their classrooms, they communicated with students both via text messages and mail. This took place during the evenings as well as on the weekends. Questions regarding the content of the films the students are watching at home were most frequently asked. The teachers in the research described this as something positive for the students' learning and for their relationship with the students. But is it reasonable for teachers to continue to 'be on call' even outside the classroom and outside the school's working hours? We think that it must be up to every professional teacher to decide on what forms of communication should take place outside school working hours and what constitutes reasonable access to the teachers. The other potential obstacle has to do with the use of technology. Technology was an important factor that was mentioned during the interviews that enabled the teaching method. The teachers included in the present research produced their own movies which they used in their flipped classrooms. This was described as time-consuming when the teachers were transitioning from traditional methods of teaching. However, it was also experienced as a time-saving strategy in a longer time perspective. The fact that the teachers in our research were so positive about producing their own movies for their flips is probably due to the selection process of our informants. The selection included teachers who had worked with the flipped classroom for at least six months. It is easily assumed that these teachers were open to using ICT in their teaching and possessed a high level of competence in using technology even before they started to flip their classrooms. Notwithstanding this observation, teachers should be able to flip their classrooms without being tech-savvy and can use existing recorded materials instead. The workload for teachers in the flipped classroom can definitely increase if all of the materials are to be produced de novo by the teachers themselves, as several studies show, including Enfield (2013), Atteberry (2013), and Avdic and Åkerblom (2015).

However, Enfield (2013) also reports in his research that finding and collecting existing materials that can be used in the Flipped Classroom can also be a time-consuming process. The teachers who took part in this research all indicated that they experience positive effects for students' learning in their Flipped Classrooms. Enfield (2013) claims that students feel that they learn better through the Flipped Classroom. But do we know whether this is actually the case? To find out, other methods need be constructed to measure the effects of the Flipped Classroom.

\begin{tabular}{|l} 
PROBLEMS \\
OF EDUCATION \\
IN THE 21 $1^{\text {st }}$ CENTURY \\
Vol. 76, No. 4, 2018 \\
\hline 461
\end{tabular} 
Johan BÄCKLUND, Martin HUGO. The paradox of the flipped classroom: One method, many intentions

\begin{abstract}
PROBLEMS
OF EDUCATION

IN THE $21^{\text {st }}$ CENTURY Vol. 76, No. 4, 2018

462 A few previous studies have been conducted to investigate the effect of the Flipped Classroom on student learning, but these studies do not show unambiguous results. Jonsson (2015) presents evidence in her report that pupils who take an active part in the Flipped Classroom get higher grades, and Zhi Chen (2014) finds that learners acquire a somewhat deeper understanding of the content taught through this teaching method. Two other studies, however, (Jensen, Kummer \& Godoys, 2015; Johnson \& Renner, 2012) show no differences at all between either surfaceor deep learning or in test results in the Flipped Classroom when compared to the traditional classroom. Learning is a complex phenomenon and if the outcome of knowledge and grades depends only on a particular demarcated aspect of teaching, such as flipping the classroom, then we can only draw uncertain conclusions, because, in reality, many different variables affect what and how people learn. This research contributes new knowledge about Swedish subject teachers' experience of the Flipped Classroom. This research can hopefully inspire other teachers who want to flip their classrooms, but it can certainly also deter some teachers, because of the changes in practice that the Flipped Classroom entails.
\end{abstract}

\title{
Conclusions
}

All of the informants express that they are flipping their classrooms, because they all are using the method of the Flipped Classroom. However, to the nine informants in this research, they do not share the same goal with the method used. Some of them express they do it to increase the levels of communication while other express they do it to save time, or free up time, in the long run. Some express the key aspect of flipping the classroom as to motivate their students by planning the activities following the flip to become more meaningful and extremely connected to it while other teachers use the method to make their students progression through the courses, subject, more visible than in the traditional classroom. This leads us to the inevitable conclusion that we express, or even imply, teachers share the same focus, or goals, when teaching when they actually do not. This is not something isolated, or even only connected, to the Swedish school system. Most likely, this relatively new method, how teacher's work inside and outside their classrooms, is something that will take some time to settle in. But when talking about it, we need to sync our stories and our focuses and aims when using it. What is the Flipped Classroom and what should the definition be?

Consequently, to deepen the understanding why teachers use the Flipped Classroom methodology, purposes with using it must be defined? In this research a lot of opportunities, as well as obstacles, have been expressed and although that tells us a lot, it is now time to not only define these purposes; the learning outcomes now also need to be explored in further research.

\section{References}

Atteberry, E. (2013, December 12). 'Flipped classrooms' may not have any impact on learning. USA TODAY. Retrieved from http://www.usatoday.com

Avdic, A., \& Åkerblom, L. (2015). Flipped classroom and learning strategies. In Jefferies, A., Cubric, M., Barton, K. \& Lilley, M. (ed.), Proceedings of 14th European Conference on e-learning (pp. 4149). Reading, UK: Academic Conferences Publishing.

Baker, J. W. (2000). The 'Classroom Flip': Using web course management tools to become the guide by the side. Paper presented at the 11th International Conference on College Teaching and Learning, Jacksonville, Florida, USA. Retrieved from http://www.classroomflip.com/files/classroom_flip_ baker_2000.pdf.

Bates, S., \& Galloway, R. (2012). The inverted classroom in a large enrolment introductory physics course: a case study. Paper presented at HEA STEM Conference, London, United Kingdom.

Bergmann, J., \& Sams, A. (2012). Flip your classroom: Reach every student in every class every day. Washington: International Society for Technology in Education.

Bergmann, J. (2016, October 12). Getting past the barriers to flipping your classroom [Blog post]. Retrieved from http://www.jonbergmann.com/category/what-is-flipped/. 
Bishop, J. L., \& Verleger, M. A. (2013). The flipped classroom: A survey of the research. Atlanta: 120th ASEE Annual Conference \& Exposition.

Brown, A. (2012): A phenomenological study of undergraduate instructors using the inverted or flipped classroom model. Retrieved from http://pepperdine.contentdm.oclc.org/cdm/ref/collection/ p15093coll2/id/348.

Bryman, A. (2015). Samhällsvetenskapliga metoder [Social research methods, third edition] Stockholm: Liber.

Creswell, J. W. (2014). Research design. London: Sage Publications, Inc.

Dalen, M. (2013). Intervju som metod [Interview as method]. Malmö: Gleerups.

Elo, S., \& Kyngäs, H. (2008). The qualitative content analysis process. Journal of Advanced Nursing, 62 (1), 107-115. doi: 10.1111/j.1365-2648.2007.04569.x.

Enfield, J. (2013) Looking at the impact of the flipped classroom model of instruction on undergraduate multimedia students at CSUN. Teachtrends: Linking Research \& Practice to Improve Learning, 57 (6) 14-27.

Graneheim, U. H., \& Lundman, B. (2004). Qualitative content analysis in nursing research: Concepts, procedures and measures to achieve trustworthiness. Nurse Education Today, 24 (2), 105-112.

Gross, D., Pietri, E. S., Anderson, G., Moyano-Camihort, K., \& Graham, M. J. (2015). Increased preclass preparation underlies student outcome improvement in the flipped classroom. CBE - Life Sciences Education, 14 (4), Article 36, 8. http://dx.doi.org/10.1187/cbe.15-02-0040.

Hattie, J. (2012). Visible learning for teachers: Maximizing impact on learning. London: Routledge.

Herreid, C. F., \& Schiller, N. A. (2013). Case study: Case studies and the flipped classroom. Journal of College Science Teaching, 42 (5), 62-67. Retrieved from https:/www.aacu.org/sites/default/files/ files/PKAL_regional/CRWG-SPEE-REF-01.pdf.

Jensen, J. L., Kummer, T. A., \& Godoy, P. D. D. M. (2015). Improvements from a flipped classroom may simply be the fruits of active learning. CBE - Life Sciences Education, 14 (1). doi:10.1187/ cbe.14-08-0129.

Johnson, L., \& Renner, J. (2012). Effect of the flipped classroom model on a secondary computer applications course: Student and teacher perceptions, questions and student achievement. Dissertation, University of Louisville. Louisville, Kentucky. Retrieved from https://theflippedclassroom.files. wordpress.com/2012/04/johnson-renner-2012.pdf.

Jonsson, H. (2015). Using flipped classroom, peer discussion, and just-in-time teaching to increase learning in a programming course. Frontiers in Education Conference (FIE), 2015. doi:10.1109/ FIE.2015.7344221.

King, A. (1993). From sage on the stage to guide on the side. College Teaching, 41 (1), 30-35. http://www. jstor.org/stable/27558571.

Kjellin, H., \& Birkenkrahe, M. (2015). Improving student interaction and engagement in the flipped classroom 14th European Conference on e-Learning, 14th European Conference on e-Learning ECEL-2015, 2015. https://books.google.se/books?id=HI5mCwAAQBAJ\&lpg=PA73\&dq=Improving\%20Student $\% 20$ Interaction $\% 20$ and $\% 20$ Engagement $\% 20$ in $\% 20$ the $\% 20$ Flipped $\% 20$ Classroom $\&$ hl $=$ sv\& $\mathrm{pg}=\mathrm{PA} 73 \# \mathrm{v}=$ onepage $\& \mathrm{q} \& \mathrm{f}=$ false.

Kroksmark, T. (2013). Förord. I Kroksmark, T. (2013). Den trådlösa pedagogiken (7-10). [Wireless pedagogy]. Lund: Studentlitteratur.

Kvale, S., \& Brinkmann, S. (2014). Den kvalitativa forskningsintervjun [The qualitative research interview]. Lund: Studentlitteratur.

Lage, M. J., Platt, G. J., \& Treglia, M. (2000). Inverting the classroom: A gateway to creating an inclusive learning environment. The Journal of Economic Education, 31 (1), 30-43. doi:10.2307/1183338.

Larsen, A-K. (2009). Metod helt enkelt [Method, quite simply]. Malmö: Gleerups.

Malterud, K. (1998). Kvalitativa metoder i medicinsk forskning [Qualitative methods in medical science]. Lund: Studentlitteratur.

McLean, S., Attardi, S. M., Faden, L., \& Goldszmidt, M. (2016). Flipped Classrooms and student learning: Not just surface gains. Advances in Physiology Education, 40 (1), 47-55. doi:dx.doi.org/10.1152/ advan.00098.2015.

Mattis, K. V. (2015). Flipped classroom versus traditional textbook instruction: Assessing accuracy and mental effort at different levels of mathematical complexity. Technology, Knowledge and Learning, 20 (2), 231-248. doi:10.1007/s10758-014-9238-0.

Mazur, E. (1997/2014). Peer instruction: A user's manual. Essex: Pearson Education Limited.

PROBLEMS

OF EDUCATION

IN THE $21^{\text {st }}$ CENTURY

Vol. 76, No. 4, 2018 
Johan BÄCKLUND, Martin HUGO. The paradox of the flipped classroom: One method, many intentions

PROBLEMS

OF EDUCATION

IN THE $21^{\text {st }}$ CENTURY

Vol. 76 , No. 4, 2018

464

Skolverket. (2011). Curriculum for the compulsory school, preschool class and the recreation centre. Stockholm: Skolverket.

Skolverket. (2013). Curriculum for the upper secondary school. Stockholm: Skolverket.

Solstuen, A. (2014). Et nytt verktøy $i$ verktøykassa - Omvendt musikkundervisning i grunnskolen [A new tool to use: The inverted music classroom in compulsory school]. Hedmark: Høgskolen i Hedmark.

Strayer, J. (2007): The effects of the classroom flip on the learning environment: A comparison of learning activity in a traditional classroom and a flip classroom that used an intelligent tutoring system. Dissertation. The Ohio State University, Columbus Ohio. Retrieved from https://etd.ohiolink. edu/!etd.send_file?accession $=$ osu1189523914.

Tesch, R. (1990). Qualitative research: Analysis types and software tools. New York: Falmer.

Van Vliet, E. A., Winnips, J. C., \& Brouwer, N. (2015). Flipped-class pedagogy enhances student metacognition and collaborative-learning strategies in higher education, but effect does not persist. CBE - Life Sciences Education, 14 (9), 1-10. doi:10.1187/cbe.14-09-0141.

Swedish Research Council. (2007). Forskningsetiska principer inom humanistisk-samhällsvetenskaplig forskning [Ethical guidelines within humanities and social sciences] Stockholm: Vetenskapsrådet. Retrieved from www.codex.vr.se/texts/HSFR.pdf.

Zhi Chen, E. (2014). Flipped classroom model and its implementation in a computer programming course. Part of: Lärarlärdom: Högskolepedagogisk konferens 2014, Blekinge Tekniska Högskola. http:// lararlardom2014.pressbooks.com/chapter/flipped-classroom-model-and-its-implementation-in-acomputer-programming-course/.

Received: April 28, 2018

Accepted: July 09, 2018

\begin{tabular}{|ll} 
Johan Bäcklund & M. Ed., PhD Student, Lecturer Educational Sciences, School of Education and Com- \\
& munication, Jönköping University, P.O. Box 1026, SE-551 11, Jönköping, Sweden. \\
& E-mail: johan.backlund@ju.se \\
& Website: https://ju.se/personinfo.html?sign=bacjoh \\
\hline Martin Hugo & PhD in Applied Educational Science, Associate Professor, School of Education and \\
& $\begin{array}{l}\text { Communication, Jönköping University, P.O. Box 1026, SE-551 11 Jönköping, Sweden. } \\
\text { E-mail: martin.hugo@ju.se } \\
\text { Website: https://ju.se/personinfo.html?sign=HMar }\end{array}$
\end{tabular}

